\title{
Cardiovascular System Findings Link Group
}

National Cancer Institute

\section{Source}

National Cancer Institute. Cardiovascular System Findings Link Group. NCI Thesaurus.

Code C162034.

A sequence of characters used to link multiple cardiovascular system findings to a single finding. 